\title{
Evaluation of asthma control by physicians and patients: Comparison with current guidelines
}

\author{
Louis-Philippe Boulet MD FRCPC ${ }^{1}$, Robert Phillips $\mathrm{PhD}^{2}$, \\ Paul O'Byrne MD FRCPC ${ }^{3}$, Allan Becker MD FRCPC ${ }^{4}$
}

L-P Boulet, R Phillips, P O’Byrne, A Becker. Evaluation of asthma control by physicians and patients: Comparison with current guidelines. Can Respir J 2002;9(6):417-423.

BACKGROUND: Current asthma consensus guidelines recommend a series of criteria for determining whether asthma is controlled. It is not known whether physicians are using these criteria to assess treatment needs and how effective such assessments are compared with patient assessment of asthma control. OBJECTIVE: To compare the parameters used by physicians and patients with asthma to determine whether asthma control is acceptable, according to the current Canadian asthma consensus guidelines.

DATA AND METHODS: A total of 183 Canadian physicians, mostly general practitioners, evaluated 856 patients with mildly to moderately uncontrolled asthma who were not using anti-inflammatory medications at the time of entry in the study. Physician characteristics and patient demographics were obtained. The physicians completed two questionnaires, one assessing the level of asthma control of the patient on an ordinal scale from 1 (very poor) to 5 (very good) and another indicating the parameters that were used to evaluate this level of control. Patients answered an asthma control questionnaire identical to the one completed by the physician and completed a six-question asthma control questionnaire, with each question scored on a 0 - to 6-point scale.

RESULTS: Although according to current asthma guidelines all patients surveyed had uncontrolled asthma, $66.2 \%$ of patients and $43.3 \%$ of physicians rated control of asthma symptoms as adequate to very good. The average scores for patient- and physician-rated asthma control were $3.0 \pm 0.2$ and $2.6 \pm 0.2$, respectively. The average patient score on the Juniper asthma questionnaire was 12.2 \pm 6.3 . Physicians used a mean of seven parameters to assess the patient's level of asthma control, mostly beta 2 -agonist need, followed by cough, wheezing, shortness of breath, limitation of physical activities and night-time awakenings. Pediatricians used cough more frequently as an evaluation parameter, and respirologists measured pulmonary function more often than other physcians. Some parameters not usually included in guideline criteria for control, such as fatigue, need to clear throat, colored sputum, headache and dizziness, were sometimes used by physicians. Only $10 \%$ and $18 \%$ of physicians used measurements of forced expiratory volume in $1 \mathrm{~s}$ and peak expiratory flow, respectively, in asthma control assessments.

CONCLUSIONS: The present study shows that the selection of asthma control criteria among physicians varies and is not always in keeping with current asthma guidelines. Both patients and physicians often consider asthma to be controlled, when according to current guidelines, it is not, and patients consider their asthma better controlled than do physicians. Objective measures of airflow obstruction are rarely used to assess asthma control. The present study stresses the need for improved dissemination to both patients and physicians - of current recommendations on how asthma control should be determined.

Key Words: Asthma control; Asthma treatment; Physicians' assessment

Résumé à la page suivante

\footnotetext{
${ }^{1}$ Institut universitaire de cardiologie et de pneumologie de l'Université Laval, Hôpital Laval, Sainte-Foy, Québec; ${ }^{2}$ Symbios RP Inc, Montréal, Québec; ${ }^{3}$ Asthma Research Group, St Joseph's Hospital, and Department of Medicine, McMaster University, Hamilton, Ontario;

${ }^{4}$ Section of Allergy and Clinical Immunology, Department of Pediatrics, University of Manitoba, Winnipeg, Manitoba

Correspondence and reprints: Dr Louis-Philippe Boulet, Hôpital Laval, 2725, chemin Sainte-Foy, Sainte-Foy, Québec GlV 4 G5.

Telephone 418-656-4747, fax 418-656-4762, e-mail lpboulet@med.ulaval.ca
} 


\section{Évaluation de la maîtrise de l'asthme par les médecins et les patients : Comparaison avec les directives actuelles}

HISTORIQUE : Les directives consensuelles actuelles sur l'asthme préconisent l'application d'une série de critères pour déterminer si l'asthme est maîtrisé. On ignore si les médecins utilisent ces critères pour évaluer les besoins thérapeutiques et on ignore quelle est l'efficacité de ces évaluations comparativement à l'évaluation que les patients peuvent faire de la maîtrise de leur asthme.

OBJECTIF : Comparer les paramètres utilisés par les médecins et les patients asthmatiques pour déterminer si la maîtrise de l'asthme est acceptable selon les directives consensuelles canadiennes sur l'asthme.

DONNÉES ET MÉTHODES : En tout, 183 médecins canadiens, la plupart généralistes, ont évalué 856 patients présentant un asthme légèrement à modérément non contrôlé qui n'utilisaient pas d'anti-inflammatoires au moment de leur admission à l'étude. Les caractéristiques des médecins et les données démographiques des patients ont été obtenues. Les médecins ont répondu à deux questionnaires, l'un évalu-ant le degré de maîtrise de l'asthme du patient sur une échelle de 1 (très faible) à 5 (très bonne) et un autre indiquant les paramètres utilisés pour évaluer ce degré de maîtrise. Les patients ont répondu à un questionnaire sur la maitrise de leur asthme identique à celui qui a été soumis aux médecins et ils ont répondu à un questionnaire de six questions sur la maîtrise de l'asthme, chaque réponse étant reportée sur l'échelle en six points.

RÉSULTATS : Bien que selon les directives actuelles en matière d'asthme tous les patients interrogés présentaient un asthme non maîtrisé,
66,2 \% des patients et 43,3 \% des médecins ont déclaré que les symptômes d'asthme étaient soit adéquatement soit très bien contrôlés. Les scores moyens quant à la maîtrise de l'asthme selon l'évaluation des patients et des médecins ont été de 3,0 $\pm 0,2$ et de 2,6 $\pm 0,2$, respectivement. Le score moyen des patients au questionnaire Juniper sur l'asthme a été de 12,2 \pm 6,3. Les médecins ont utilisé en moyenne sept paramètres pour évaluer le degré de maîtrise de l'asthme de leurs patients, principalement le recours aux bêta ${ }_{2}$-agonistes suivi de la toux, des sillements, de l'essoufflement, de la restriction des activités physiques et des réveils nocturnes. Les pédiatres ont utilisé la toux plus souvent comme paramètre d'évaluation et les pneumologues ont mesuré la fonction pulmonaire plus souvent que les autres médecins. Certains paramètres généralement exclus des critères de maîtrise préconisés par les directives, comme la fatigue, les raclements de gorge, les expectorations colorées, la céphalée et les étourdissements, ont parfois été utilisés par les médecins. Seulement $10 \%$ et $18 \%$ des médecins ont utilisé des mesures de VEMS et débit expiratoire de pointe, respectivement, dans leurs évaluations de la maîtrise de l'asthme.

CONCLUSION : La présente étude montre que les médecins adoptent différents critères pour mesurer la maîtrise de l'asthme et que ces critères ne concordent pas toujours avec les directives actuelles. Les patients et les médecins considèrent souvent que l'asthme est maîtrisé alors que selon les directives actuelles, il ne l'est pas et les patients considèrent leur asthme mieux maîtrisé que leur médecin. Les mesures objectives d'obstruction bronchique sont rarement utilisées pour évaluer la maîtrise de l'asthme. La présente étude rappelle la nécessité de mieux faire connaître aux médecins et aux patients les recommandations actuelles sur la façon dont on doit mesurer le degré de maîtrise de l'asthme.
$\mathrm{I}_{\mathrm{p}}^{\mathrm{t}}$ is recommended that asthma treatment be based on the patient's degree of asthma control, and the current asthma consensus guidelines recommend a series of criteria to be used to determine whether asthma is adequately controlled $(1,2)$. These criteria usually include the minimal use of short-acting beta ${ }_{2}$-agonists, minimal or no respiratory symptoms, and the ability to conduct normal daily activities, in addition to optimal pulmonary function.

Physicians do not always know practice guidelines, and the guidelines' recommendations are only partially followed $(3,4)$. Although the asthma guidelines only guide practice, some general principles about how to assess asthma control and the need for objective measures of airflow obstruction are important recommendations. However, in their daily practices, physicians use mostly subjective measures to assess asthma control. We do not know, however, whether the criteria suggested by the current guidelines are used regularly in practice and whether a given physician's assessment of asthma control is consistent with that of the patient with asthma.

The present study looked at adult and pediatric patients diagnosed with mild to moderate asthma. Its objectives were: to identify the parameters used by physicians in determining asthma control; to compare patient's perception of asthma control with the findings of a validated asthma control questionnaire; to compare physician's and patient's perceptions of asthma control; and to compare those results with recommendations of the 1999 Canadian Asthma Consensus Report on asthma control assessment (1).

\section{DATA AND METHODS}

Patient recruitment and study design

The present analysis used baseline data from a noncontrolled, observational, open-label study on changes in asthma control following the introduction of montelukast sodium in patients with uncontrolled asthma who were not using anti-inflammatory medications. Two hundred thirtytwo physicians were asked to recruit prospectively five patients, six years of age and older, with a diagnosis of mild to moderate asthma. Physicians were recruited consecutively from a list of potential investigators.

Patients could be enrolled in the program if they were currently using a beta ${ }_{2}$-agonist on demand more than three and less than 15 times a week (eight to 28 inhalations); if they required inhaled corticosteroid therapy but could not or would not use this type of therapy (1); and if, in the treating physician's clinical judgment, they would benefit from leukotriene antagonist therapy. The severity of asthma could be considered mild to moderate according to current criteria (1). After obtaining informed consent, the treating physician and the patient independently completed their asthma questionnaires.

\section{Questionnaires}

The information collected on the questionnaire given to physicians consisted of physician identification and specialty, along with the baseline demographics of the patient: age, sex, race, number of years since the first diagnosis of asthma and status of prior asthma therapy. The physician assessed 
the patient's level of asthma control on an ordinal scale from 1 (very poor) to 5 (very good). Treating physicians were also asked to indicate, from a list of 20 parameters, the ones that they used to assess each patient's level of asthma control. The choices consisted of 18 asthma-related symptoms and two pulmonary function tests, forced expiratory volume in one second $\left(\mathrm{FEV}_{1}\right)$ and peak expiratory flow $(\mathrm{PEF})$.

The information collected at baseline from the patient came from a six-question asthma control questionnaire developed by Juniper et al (5), where each question was scored on a 0 to 6 scale (better to worse). Using a validated questionnaire provided another means of assessing asthma control. Patients also assessed asthma control on an ordinal scale from 1 (very poor) to 5 (very good). The patients were asked: "How would you rate the control of your asthma symptoms (on a five point scale from very good to very poor)?". For children, parents were asked to answer the questionnaires and assess control. Data collected for each patient were faxed, after each visit, to Symbios RP Inc (Montreal, Quebec) that was responsible for data collection.

\section{Data analysis}

Descriptive statistics were calculated on all data collected during the program. This included verifying data for consistency with expected ranges of all variables, and descriptive statistics (such as means, medians, ranges, standard deviations and percentages) obtained with regard to the identification of the asthma control parameters used by physicians, the number of times that each physician answered yes to each symptom and the rankings of the 20 symptoms (from most commonly used to least commonly used), according to the physician specialty (pediatrician, general practitioner, and community allergist/respirologist). Data were also analyzed by level of asthma control, as assessed by the physician (five categories); level of asthma control, as assessed by the patient (five categories); total asthma symptom score by the patient; and patient age group by either adult (age 15 or older) or child (age 14 or under). The $95 \%$ Cls were calculated wherever warranted.

For comparison of the patient's perception of asthma control in relation to the Juniper asthma control questionnaire, the overall score for each patient was calculated as the sum of the scores for each question. Because each question was scored from 0 to 6 , the maximum possible score was 36 and the minimum was 0 . The mean \pm SD and percentage of patients with each possible score value were calculated, along with a Spearman's correlation coefficient of this score with the patient's overall control rating (scored from 1 to 5). A similar correlation coefficient was calculated for the physician's overall rating of the patient's control.

For comparison of the physician's and patient's perceptions of asthma control, the proportion of the patients reporting each category of control (from 1 [very good] to 5 [very poor]) was compared with the same measurement from the physicians. A paired difference (patient-physician) of the control category was created, where the cate-
TABLE 1

Baseline demographics by patient category in a survey of patient asthma control

\begin{tabular}{lccc}
\hline & $\begin{array}{c}\text { Total sample } \\
(\mathbf{n = 8 5 6})\end{array}$ & $\begin{array}{c}\text { Adult } \\
\text { patients }\end{array}$ & $\begin{array}{c}\text { Pediatric } \\
\text { patients }\end{array}$ \\
\hline Patient category (\%) & 100 & 70.8 & 29.2 \\
$\begin{array}{l}\text { Age (years) } \\
\quad \text { (average } \pm \text { SD) }\end{array}$ & $33 \pm 17$ & $42 \pm 17$ & $9 \pm 3$ \\
Sex & & & \\
$\quad$ Male (\%) & & & \\
$\quad$ Female (\%) & 52 & 47.2 & 64.9 \\
$\begin{array}{l}\text { Time since diagnosis } \\
\quad \text { (years) (average } \pm \text { SD) }\end{array}$ & $8.9 \pm 9.5$ & 52.8 & 35.1 \\
& & & \\
\end{tabular}

gories were numbered 1 through 5 , and the average difference and average absolute difference were reported with 95\% CIs (the average of the patient-physician scores). The average absolute difference was the absolute difference between the scores of the two groups, irrespective of the direction of the change. Tests for patient-physician differences were carried out. A five by five cross-tabulated table was created displaying all possible results for patients and physicians, where the diagonal elements represent agreement and the off-diagonal elements represent disagreement between the patients and physicians. Overall analyses were performed, combining data from all patients, and separate analyses for pediatric and adult cases were performed.

\section{RESULTS}

\section{Physician and patient baseline enrolment data}

A total of 183 physicians of 232 initially recruited (78.9\%) evaluated 856 patients between April and December 1999. Patient status data are shown in Table 1. The average age recorded for the adults recruited was $42.0 \pm 16.9$ years; for children, it was $9.4 \pm 2.6$ years. Although the male to female ratio was similar in the total sample and adult groups (52\%:48\% and $47.2 \%: 52.8 \%$ respectively), for children, the number of boys was almost double that of girls (64.9\%:35.1\%). The time elapsed since asthma diagnosis was $8.9 \pm 9.5$ years for all patients enrolled, $10.8 \pm 10.5$ years for adult patients and $4.5 \pm 3.1$ for pediatric patients. Most patients were white $(90.3 \%)$.

The sample of 183 recruiting physicians consisted of $73.8 \%$ general practitioners, $14.2 \%$ allergists and respirologists, and $12.0 \%$ pediatricians; the three groups enrolled $74.6 \%, 11.7 \%$ and $13.7 \%$, respectively, of the patients in the study. As expected, the great majority of patients recruited by pediatricians were children $(94.5 \%)$, whereas general practitioners, and allergists and respirologists had a $4: 1$ adult to child age distribution recruitment ratio. General practitioners recruited $85.8 \%$ of all adults and $47 \%$ of all children; allergists and respirologists, $13.2 \%$ and $8 \%$, respectively; and pediatricians, $1 \%$ and $45 \%$, respectively. 

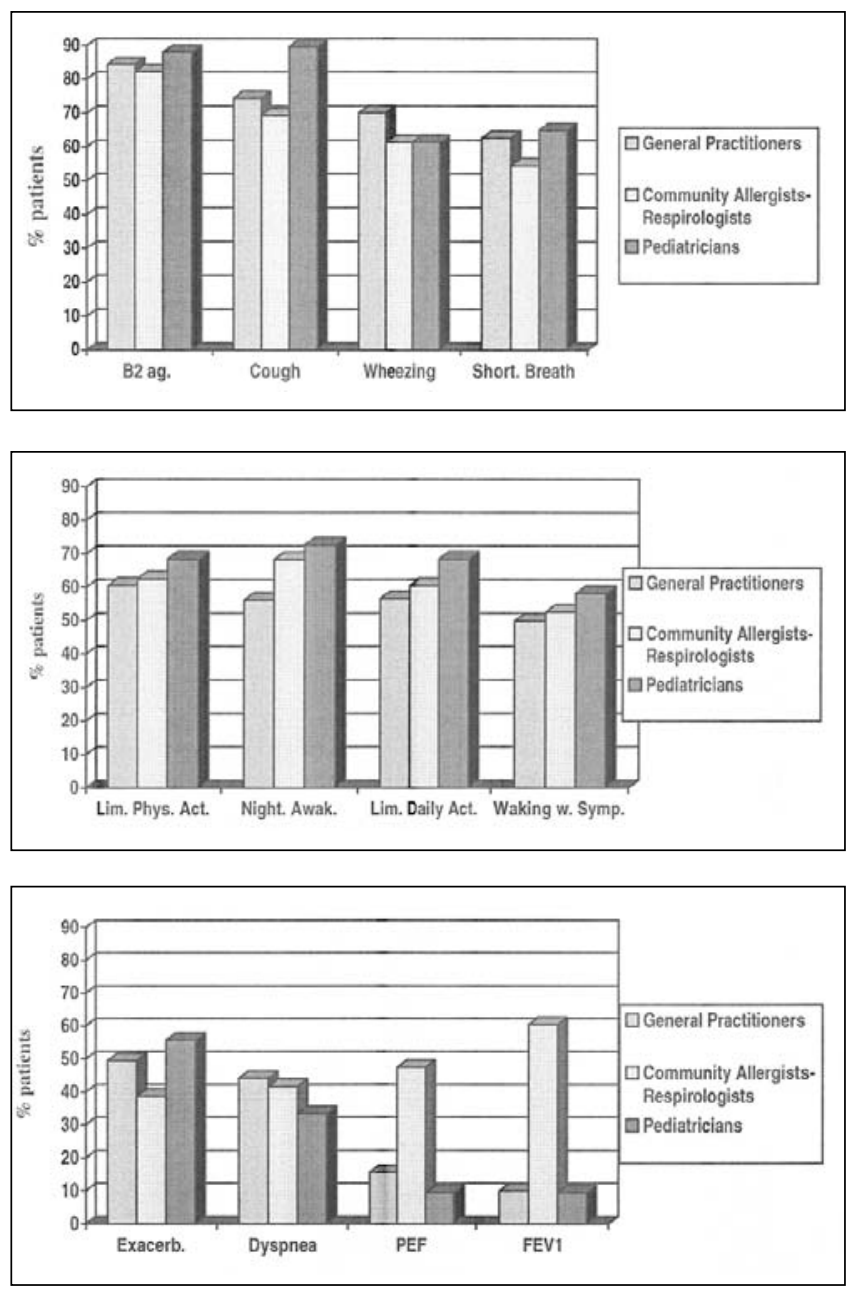

Figure 1) Most common parameters used by physicians to assess asthma control in a survey of patient asthma control. FEV Forced expiratory volume in $1 \mathrm{~s}$; PEF Peak expiratory flow

\section{Identification of the asthma control parameters used by physicians}

Recruiting physicians reported using approximately seven parameters to assess their patients' level of asthma control throughout the study. Figure 1 shows the most frequently mentioned criteria. In total, 10 asthma-related parameters were used by physicians in assessing the level of asthma control (in more than $40 \%$ of patients) (Figure 1). Beta 2 agonist use was the most frequently employed parameter. It was used to evaluate asthma control in over $80 \%$ of all patients, followed by cough and wheezing in over $65 \%$ of all patients. The parameters, shortness of breath, limitations in physical activities and night-time awakenings, were used in approximately $60 \%$ of all patients. The remaining parameters not illustrated in Figure 1 were used by physicians in $25 \%$ or less of patients during the three visits. They include some criteria not currently suggested in asthma guidelines, such as fatigue and the need to clear throat.

Compared with other physician specialties, pediatricians used cough more frequently as an asthma evaluation parameter, while community allergists and respirologists used
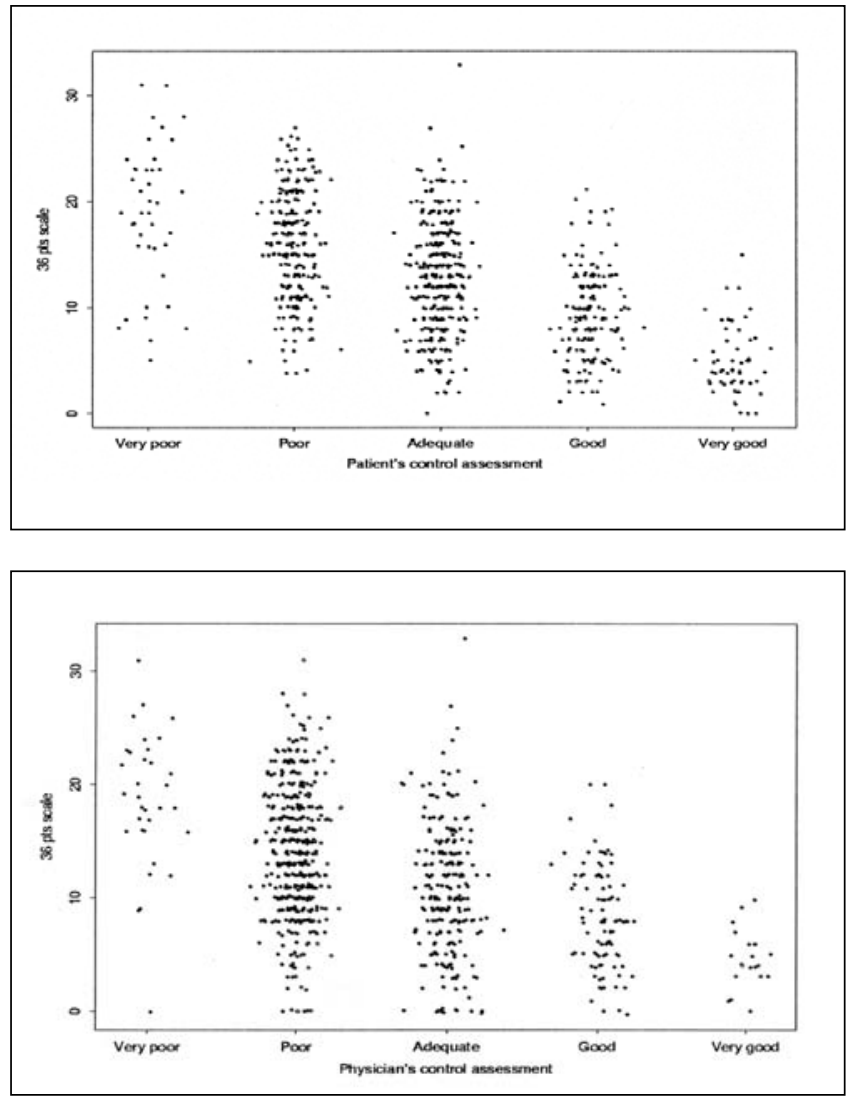

Figure 2) Patient (top) and physician (bottom) control assessment compared with a 36-point asthma-control questionnaire in a survey of patient asthma control

cough less frequently than primary care physicians. Overall, objective measures of airflow obstruction were rarely used to assess asthma control, with $\mathrm{FEV}_{1}$ being obtained at the office for only $10 \%$ of patients and PEF for only $18 \%$. Community allergists and respirologists used $\mathrm{FEV}_{1}$ and $\mathrm{PEF}$ significantly more often than primary care practitioners (in $61 \%$ and $48 \%$ of patients, respectively).

Comparison of the patient's perception of asthma control in relation to an asthma-control questionnaire

The control of asthma symptoms was rated as very poor or poor by $33.8 \%$ of patients and $56.7 \%$ of physicians; as adequate by $38.2 \%$ of patients and $28.6 \%$ of physicians; and as good by $21 \%$ of patients and $12.2 \%$ of physicians (Figure 2). Patients reported the rating of 'very good' for baseline asthma symptom control 2.5 times more frequently than physicians (6.8\% versus $2.6 \%)$. When using the five-point asthma control assessment, the mean $\pm \mathrm{SD}$ of baseline scores for patient-rated asthma control was $3.0 \pm 0.2$; it was $2.6 \pm 0.2$ for the physician-rated score. The average patient Juniper asthma questionnaire score was $12.2 \pm 6.3$. The correlation coefficient between the asthma questionnaire scores and the level of control at baseline was slightly higher for patients than it was for physicians $(-0.56$ versus -0.44$)$. 
Comparison of physician and patient perceptions of asthma control

Figure 3 illustrates the differences in patients' and physicians' levels of perception of asthma control. Physicians and patients posted identical asthma control level scores $50 \%$ of the time. In general, patients tended to score their level of asthma control higher than did physicians. In fact, $39.4 \%$ of patients presented higher scores than those assigned by their treating physicians. The remaining $10.6 \%$ of patients reported lower levels of control than did their treating physicians. Overall, patients gave higher average scores of asthma control than physicians, and both reported higher average scores than guidelines recommend.

For short-acting beta ${ }_{2}$-agonist use (Table 2), patients considered their asthma better controlled than physicians for a certain degree of intake of these agents; even when such agents were used frequently, both physicians and patients sometimes considered the asthma to be sufficiently controlled. The authors of the present paper could not, however, determine whether patients were using these agents on demand or on a regular basis.

\section{DISCUSSION}

There is a need to evaluate how physicians and patients determine asthma control and how their methods compare with those recommended in the current asthma guidelines $(1,2)$. The present study showed that both patients and physicians often consider asthma to be controlled when current guidelines would not, and that patients often consider their asthma to be better controlled than their physicians do. The selection of asthma

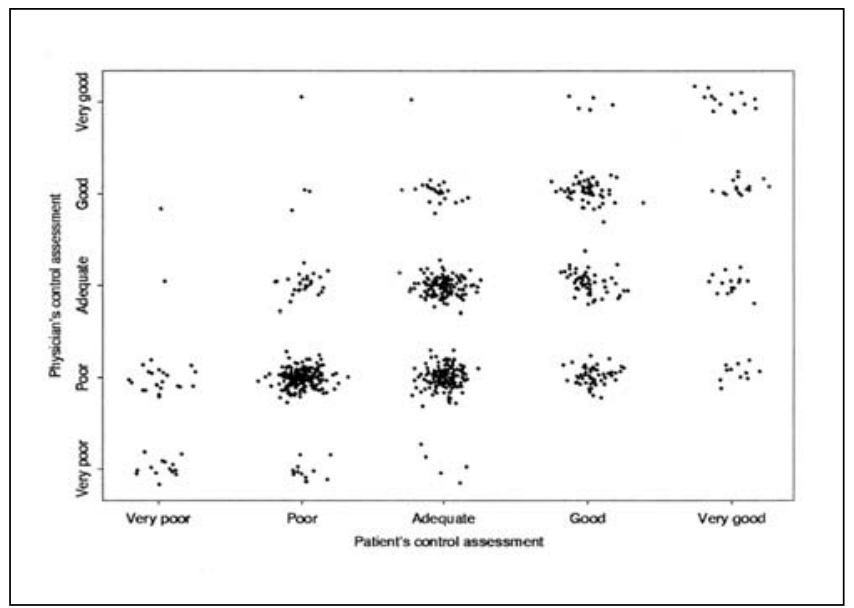

Figure 3) Patients' compared with physicians' perception of asthma control in a survey of patient asthma control

control criteria among physicians varied and was not always in keeping with the current asthma guidelines. Objective measures were rarely used to assess asthma control, except by community allergists and respirologists who measured pulmonary function in most of their patients.

Asthma severity and control are often considered to be interchangeable, but previous publications stress the need to differentiate between the two aspects of the disease (6-8). Although the accepted definition of 'controlled asthma' has changed over the years, the recent asthma consensus guidelines are relatively similar in regard to those criteria $(1,2)$. There is evidence, however, that physicians

TABLE 2

Level of asthma control for children and adults compared with short-acting beta ${ }_{2}$-agonist use

\begin{tabular}{|c|c|c|c|c|c|c|c|c|}
\hline \multirow{3}{*}{$\begin{array}{l}\text { Children } \\
\text { Control } \\
\text { of symptoms }\end{array}$} & \multicolumn{8}{|c|}{ Use of beta ${ }_{2}$-agonist (puffs/day) (\%) } \\
\hline & \multicolumn{2}{|c|}{ No use } & \multicolumn{2}{|c|}{1 to 2} & \multicolumn{2}{|c|}{3 to 8} & \multicolumn{2}{|c|}{$>9$} \\
\hline & $\begin{array}{l}\text { Phys } \\
(n=61)\end{array}$ & $\begin{array}{c}\text { Pat } \\
(n=60)\end{array}$ & $\begin{array}{l}\text { Phys } \\
n=74)\end{array}$ & $\begin{array}{c}\text { Pat } \\
(n=73)\end{array}$ & $\begin{array}{l}\text { Phys } \\
(\mathrm{n}=77)\end{array}$ & $\begin{array}{c}\text { Pat } \\
(n=81)\end{array}$ & $\begin{array}{l}\text { Phys } \\
(n=10)\end{array}$ & $\begin{array}{c}\text { Pat } \\
(\mathrm{n}=10)\end{array}$ \\
\hline Very poor & 1.6 & 5.0 & 1.4 & 2.7 & 6.5 & 7.4 & 10.0 & 10.0 \\
\hline Poor & 44.3 & 28.3 & 52.7 & 23.3 & 45.5 & 30.9 & 70.0 & 60.0 \\
\hline Adequate & 26.2 & 28.3 & 23.0 & 43.8 & 39.0 & 39.5 & 20.0 & 30.0 \\
\hline Good & 19.7 & 18.3 & 16.2 & 23.3 & 9.0 & 22.2 & - & - \\
\hline Very good & 8.2 & 20.1 & 6.7 & 6.9 & - & - & - & - \\
\hline Adults & \multicolumn{6}{|c|}{$\begin{array}{l}\text { Use of beta }{ }_{2} \text {-agonist (puffs/day) (\%) } \\
1 \text { to } 2 \\
3 \text { to } 8\end{array}$} & \multicolumn{2}{|c|}{$>9$} \\
\hline $\begin{array}{l}\text { Control } \\
\text { of symptoms }\end{array}$ & $\begin{array}{l}\text { Phys } \\
(\mathrm{n}=85)\end{array}$ & $\begin{array}{c}\text { Pat } \\
(\mathrm{n}=83)\end{array}$ & $\begin{array}{l}\text { Phys } \\
(n=155)\end{array}$ & $\begin{array}{c}\text { Pat } \\
(n=163)\end{array}$ & $\begin{array}{l}\text { Phys } \\
(n=254)\end{array}$ & $\begin{array}{c}\text { Pat } \\
(n=259)\end{array}$ & $\begin{array}{l}\text { Phys } \\
(n=42)\end{array}$ & $\begin{array}{c}\text { Pat } \\
(n=44)\end{array}$ \\
\hline Very poor & 5.9 & 7.2 & 0.7 & 1.2 & 3.1 & 3.5 & 21.4 & 22.7 \\
\hline Poor & 49.4 & 26.5 & 40.0 & 16.6 & 65.0 & 35.1 & 57.2 & 36.4 \\
\hline Adequate & 28.2 & 34.9 & 32.2 & 36.8 & 24.8 & 41.3 & 21.4 & 36.4 \\
\hline Good & 10.6 & 18.1 & 23.9 & 36.2 & 6.7 & 16.2 & - & 4.5 \\
\hline Very good & 5.9 & 13.3 & 3.2 & 9.2 & 0.4 & 3.9 & - & - \\
\hline
\end{tabular}

Pat Patient; Phys Physician 
are not following many of the recommendations in the current guidelines, particularly those related to the assessment of asthma severity and control (9).

Reports from different countries suggest that many patients with asthma have far from optimal control $(9-14)$. This problem may stem from a number of causes, including insufficient treatment, underassessment of asthma severity or control, poor compliance with treatment, insufficient patient education and socioeconomic factors (15-17). The parameters used by physicians to assess asthma and treatment needs are most important in this regard.

The present study shows that asthma control is assessed primarily from clinical symptoms and rescue treatment needs, while objective measurements of airflow obstruction are rarely carried out by primary care practitioners. This is in keeping with previous observations (9). However, subjective assessment of asthma may be problematic, because there is often a discrepancy between the perception of asthma control or severity and pulmonary function $(18,19)$. Temporal adaptation and poor perception or denial of symptoms are implicated in these differences $(20,21)$. Community allergists and respirologists were more inclined to use spirometry to assess asthma, but even simple devices such as peak flow meters often were not used by other physicians. These findings are in contrast with the recommendations of the current asthma guidelines, which state that objective measures of airflow obstruction are a most useful means of assessing asthma control $(1,2)$.

The use of expiratory flow measurements in the physician's office is infrequent in general practice $(9,22,23)$. Among the most common reasons offered for not using these tests is the unavailability of the equipment and technical assistance needed to carry them out, although this should be less of a problem with PEF measures. It seems that many physicians have not integrated these tests into their current practice, and that even when the tests are performed, the quality of the tests may not be optimal or there may be difficulties with the interpretation of the results $(23,24)$. Solutions to the problem of the underuse of such tests include increased availability of pulmonary function tests in experienced laboratories; improved training of physicians and their personnel; increased awareness among physicians of the usefulness of the tests so that they would agree to use them; and the development of additional tools to facilitate the use of the tests, such as less expensive electronic spirometers.

It was surprising that many physicians considered their patients' asthma well controlled, while in the inclusion criteria for the study, they had evidence of poor asthma control - a greater than recommended use of short-acting beta $_{2}$-agonists and frequent symptoms. This suggests that physicians may not agree with or have misinterpreted the current guidelines' criteria for asthma control. Some may consider current asthma guidelines criteria too stringent and consider, in some instances or generally, that asthma is sufficiently controlled even if the asthma control does not fulfill those criteria.

Regarding the use of short-acting beta ${ }_{2}$-agonists, regular use of beta 2 -agonists is not recommended, but we cannot exclude the possibility that some patients used these agents regularly instead of 'on demand'. However, as suggested by the results presented in Table 2, even with the quite frequent use of beta 2 -agonists, patients and physicians often considered asthma as adequately or well controlled. There may be an apparent discrepancy between this observation and current guidelines, but this may simply indicate that the cut-off in number of daily puffs that indicate poor asthma control is higher for patient and physician than in guidelines.

Perception of illness is critical and has a direct impact on treatment. Our analyses suggest that, in relation to current consensus guideline criteria, physicians tend to overestimate the level of asthma control of their patients, and that patients do so even more markedly. Because the degree of asthma control may significantly affect asthma-related morbidity, further education should be offered to help patients to recognize insufficient control of their asthma and to seek help or adjust their treatment. PEF measures could also help to assess asthma control better. Asthma control questionnaires may be useful as reminders of control criteria, but although they are frequently used in research, they seem to be rarely used in primary care practice. Ideally, these questionnaires should be brief, relevant and suitable for selfcompletion by patients with asthma.

There was a discrepancy between the perception of asthma control between physicians and patients. This may relate to insufficient knowledge of what qualifies as 'well controlled asthma' or to the tendency of patients to underestimate their disability. Such observations have been mentioned in the past for other aspects of patient care $(25,26)$.

\section{CONCLUSIONS}

Physicians use different asthma control criteria that are sometimes not in keeping with the current criteria for assessing asthma control found in consensus guidelines. This is particularly true for objective measures of airflow obstruction by primary care practitioners, which are rarely used for this purpose by doctors other than respirologists or allergists. Patients generally consider their asthma to be better controlled than physicians do, but even for physicians, asthma control is often overestimated, according to current guidelines. This result stresses the need to improve the dissemination of the current recommendations regarding how asthma control is determined and should encourage the use of simple, standardized tools such as an asthma control questionnaire.

ACKNOWLEDGEMENTS: The authors thank Merck Frosst Canada \& Co for supporting this work, and are particularly grateful to Harvey Lyman and Jean-JacquesTiberi for their support and comments. 


\section{REFERENCES}

1. Boulet LP, Becker A, Bérubé D, Beveridge R, Ernst P. Canadian Asthma Consensus Report. CMAJ 1999;161(Suppl 11):S1-62.

2. International Consensus Report on the diagnosis and management of asthma. Clin Exp Allergy 1992;22(Suppl):1-72.

3. FitzGerald JM. Asthma guidelines and their impact. Can J Diagn 1994;11(Suppl):13-7.

4. Grimshaw JM, Russell IT. Effect of clinical practice guidelines on medical practice: a systematic review of rigorous evaluations. Lancet 1993;342:1317-22

5. Juniper EF, O'Byrne PM, Guyatt GH, Ferrie PJ, King DR. Development and validation of a questionnaire to measure asthma control. Eur Respir J 1999;14:902-7.

6. Cockcroft DW, Swystun VA. Asthma control versus asthma severity. J Allergy Clin Immunol 1996;98:1016-8.

7. Bernstein IL. Treatment decisions of asthma based on a paradigm of clinical severity. J Allergy Clin Immunol 1985;76:357-65.

8. Fried RA, Miller RS, Gren LA, Sherrod P, Nutting PA. The use of objective measures of asthma severity in primary care. J Fam Pract 1995;41:139-43

9. Jin R, Choi BCK, Chan BTB, et al. Physician's asthma management practices in Canada. Can Respir J 2000;7:456-65.

10. Chapman KR, Ernst P, Grenville A, Dewland P, Zimmerman S. Control of asthma in Canada: failure to achieve guideline targets. Can Respir J 2001;8(Suppl A):35-40.

11. Boulet LP. Perception of the role and potential side-effects of inhaled corticosteroids among asthmatic patients. Chest 1998;113:587-92.

12. Bousquet J, Knani J, Henry C, et al. Undertreatment in a nonselected population of adult patients with asthma. J Allergy Clin Immunol 1996;98:514-21.

13. Osborne ML, Vollmer WM, Linton KLP, Buist AS. Characteristics of patients with asthma within a large HMO. Am J Respir Crit Care Med 1998;157:123-8.

14. Turner-Warwick M. Epidemiology of nocturnal asthma. Am J Med 1988;35(Suppl 1B):6-8.
15. Sears MR. Epidemiologic trends in asthma. Can Respir J 1996;3:261-7.

16. Kendrick AH, Higgs CMB, Whitfield MJ, Laszlo G. Accuracy of perception of severity of asthma: patients treated in general practice. BMJ 1993;307:422-4.

17. Jones KP, Bain DJG, Middleton M, Mullee MA. Correlates of asthma morbidity in primary care. BMJ 1992;304:361-4.

18. Teeter JG, Bleecker ER. Relationship between airway obstruction and respiratory symptoms in adult asthmatics. Chest 1998;113:273-7.

19. Holleman DR, Simel DL, Goldberg JS. Diagnosis of obstructive airways disease from the clinical examination. J Gen Intern Med 1993;8:63-8.

20. Nouwen A, Freeston MH, Cournoyer I, Deschesnes F, Boulet LP. Perceived symptoms and discomfort during induced bronchospasm: the role of temporal adaptation and anxiety. Behav Res Ther 1994;32:623-8.

21. Boulet LP, Turcotte H. Perception scoring of induced bronchoconstriction as an index of awareness of asthma symptoms. Chest 1994;105:1430-3.

22. Grant EN, Moy JN, Turner-Roan K, Daugherty SR, Weiss KB. Asthma care practices, perceptions, and beliefs of Chicago-area primary-care physicians. Chest 1999;116:145S-54S.

23. Chan B, Anderson G, Dales RE. Spirometry utilization in Ontario: practice patterns and policy implications. CMAJ 1997;156:169-76

24. Eaton T, Withy S, Garrett JE, Mercer J, Whitlock RM, Rea HH. Spirometry in primary care practice: the importance of quality assurance and the impact of spirometry workshops. Chest 1999;116:416-23

25. Shim CS, Williams MH. Evaluation of the severity of asthma: patients versus physicians. Am J Med 1980;68:11-3.

26. Fix A, Sexton M, Langenberg P, Santanello N, Hyndman S, Williams R. The association of nocturnal asthma with asthma severity. J Asthma 1997;34:329-36. 


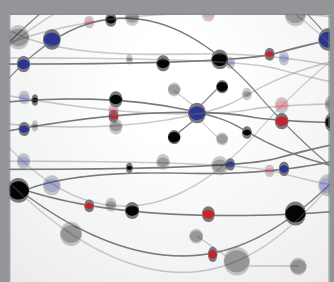

The Scientific World Journal
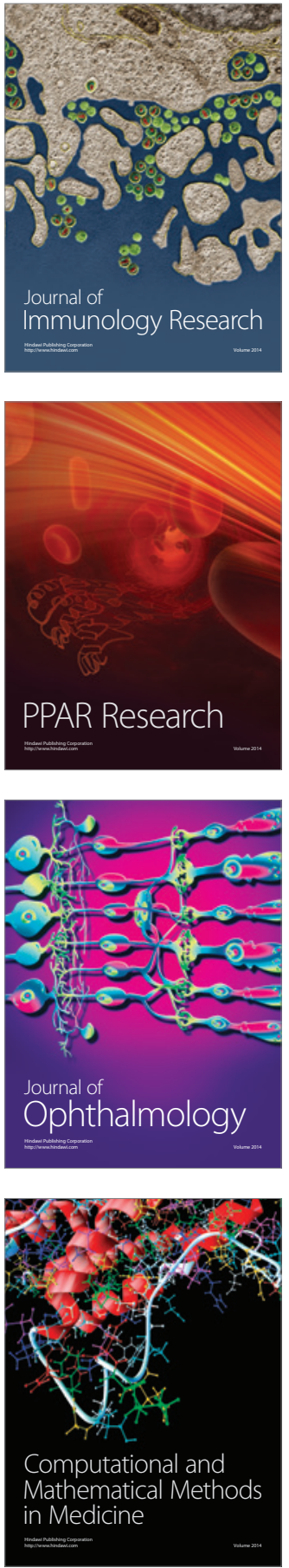

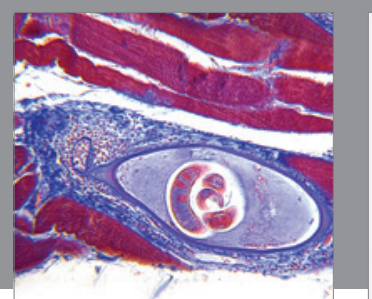

Gastroenterology Research and Practice

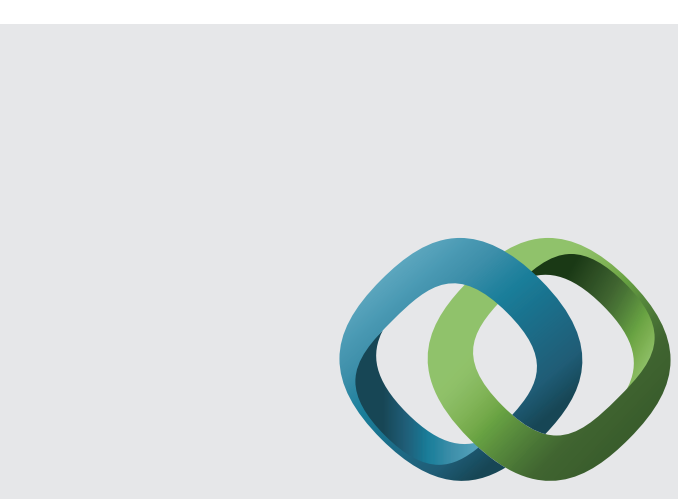

\section{Hindawi}

Submit your manuscripts at

http://www.hindawi.com
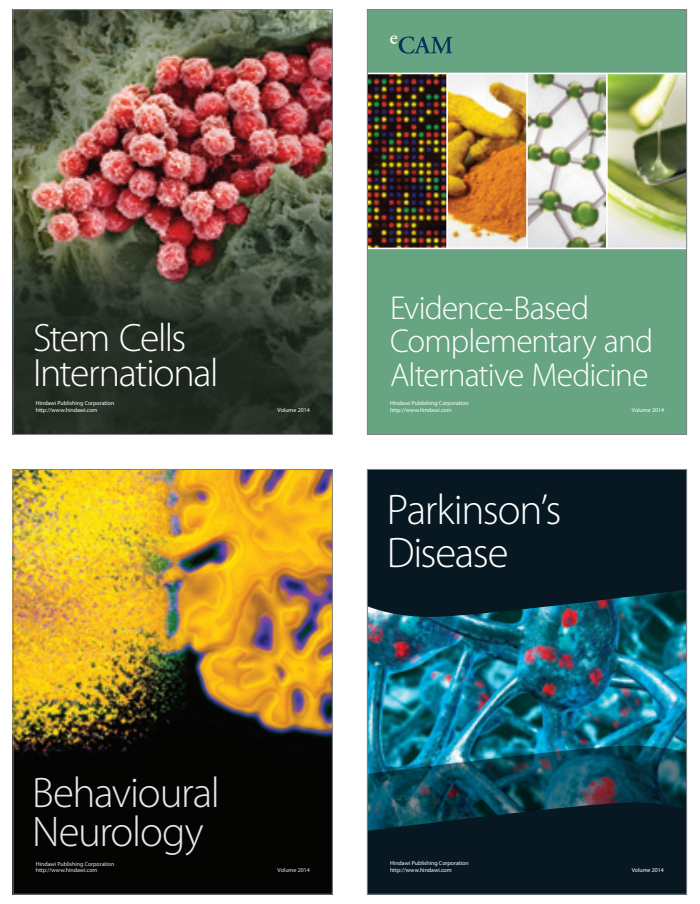
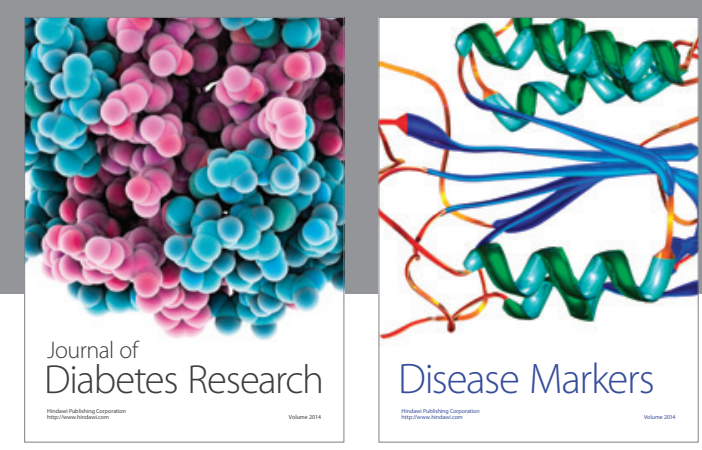

Disease Markers
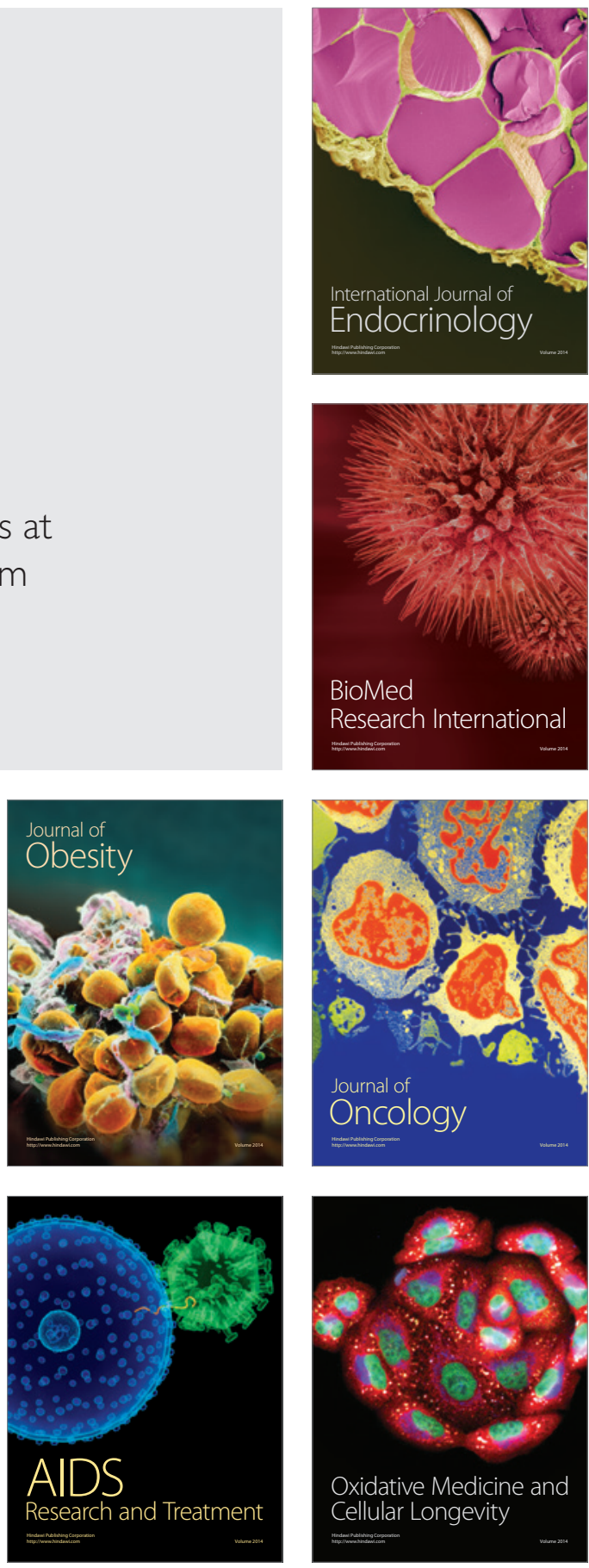